\title{
Small-mammal assemblages inhabiting Sphagnum peat bogs in various regions of Poland
}

\author{
MATEUSZ CIECHANOWSKI ${ }^{1}$, JAN CICHOCKI ${ }^{2}$, AGNIESZKA WAŻNA ${ }^{2}$ \\ and BARBARA PIŁACIŃSKA \\ ${ }^{1}$ Department of Vertebrate Ecology and Zoology, University of Gdańsk, al. Legionów 9, \\ 80-441 Gdańsk, Poland \\ ${ }^{2}$ Department of Zoology, Faculty of Biological Sciences, University of Zielona Góra, \\ ul. prof. Z. Szafrana 1, 65-516 Zielona Góra, Poland \\ ${ }^{3}$ Department of Systematic Zoology, Adam Mickiewicz University, Umultowska 89, \\ 61-614 Poznań, Poland \\ Corresponding author: Mateusz Ciechanowski, matciech@kki.net.pl
}

(Received on 19 May 2011; Accepted on 1 March 2012)

\begin{abstract}
We studied species composition of assemblages of small mammals (rodents and shrews) inhabiting Polish 25 ombrotrophic mires and quaking bogs in several regions in order to reveal characteristic features of their quantitative structure and compare them between regions, internal zones of the bog habitats, and different levels of anthropogenic degradation. We reviewed also all published results of small-mammal trapping in such habitats. Mammals were captured in pitfalls, snap traps and live traps on 12 bogs of the Pomerania region, 4 bogs of the Orawa-Nowy Targ Basin (Kotlina Orawsko-Nowotarska), 3 bogs in the Świętokrzyskie Mts, and 6 bogs in Wielkopolska and the Lubusz Land. Additionally, we included materials collected from Barber traps (pitfalls) used during studies of epigeic invertebrates on 4 bogs. In total, 598 individuals of 12 species were collected. The number of pitfall captures per 100 trapnights was very low (7.0-7.8), suggesting low population density. Shrews predominated among mammals captured in pitfalls, and the assemblage structure appeared to be similar to impoverished forest fauna, slightly enriched with ubiquitous species from meadows and agroecosystems, with a very small percentage of typical wetland species (Neomys fodiens, Neomys anomalus, Microtus oeconomus). Rodents (mostly Myodes glareolus) predominated only in samples obtained by live and snap traps. Pygmy shrew Sorex minutus was the most numerous species at most sites, sometimes being the only small mammal in that habitat, especially in well-preserved, treeless parts of bogs, dominated by Sphagnum peatmoss. The dominance and high constancy of $S$. minutus appear to be a characteristic feature of small-mammal assemblages inhabiting ombrotrophic mires, at least in some regions of Central and Western Europe. Enrichment of the fauna with other species might be related to either improved trophic conditions (by contact with mineralized ground waters) or habitat degradation (by peat mining, drainage, and subsequent secondary succession).
\end{abstract}

Key words: Rodentia, Soricomorpha, ombrotrophic bogs, raised bogs, assemblage structure, habitat occurrence 


\section{INTRODUCTION}

Raised bogs and transitional mires are collectively referred to as Sphagnum peat bogs. This group of related habitats is characterized by dominant peatmosses (Sphagnum spp.), responsible for peat formation. Sphagnum bogs may be formed in various conditions: either by growing up cupolas of acidic peat supplied with water almost exclusively by rain (purely ombrotrophic conditions) on drainage divides, or by acidification of more eutrophic fens, supplied originally by ground water (starting from minerotrophic conditions), or by terrestrialization of dystrophic lakes by floating mats of sedges and mosses (quaking bogs). Except for peatmosses, the vegetation of such habitats is usually dominated by small (not tufted) sedges, ericaceous shrubs, and, if the water level is low enough, pine and birch trees (EllenBERG \& STRUTT 1988). All these environments are considered relatively challenging for animals and plants, because of a combination of high water level, extremely low $\mathrm{pH}(3.0-4.5)$, abundance of humic acids, and scarcity of nutrients (SPEIGHT \& BLACKITH 1983).

Some organisms evolved as stenotopic inhabitants of Sphagnum bogs, being classified as tyrphophilous (preferring peat substrate), tyrphobiontic (living exclusively on peat bogs) or sphagnicolous (associated with peatmoss). These are e.g. carnivorous plants (sundews Drosera spp.) and several invertebrates, either aquatic or terrestrial (SPEIGHT \& BLACKITH 1983). Much less is known about the vertebrate fauna of Sphagnum peat bogs, including small mammals. In the Nearctic at least 2 species of microtine rodents (northern bog lemming Synaptomys borealis and southern bog lemming Synaptomys cooperi), as well as Arctic shrew Sorex arcticus, are suggested to be tyrphophilous (MAZEROLLE et al. 2001), although all these species prefer other types of wetlands, including minerotrophic ones (NORDQUIST 1992). Furthermore, the small-mammal fauna of Nearctic ombrotrophic mires is rich in species and responds to anthropogenic degradation associated with peat mining (MAZEROLLE et al. 2001). Much less has been published about small mammals associated with Sphagnum peat bogs in the Palaearctic (e.g. Boström \& Hansson 1981; Koneva 1983), in contrast to the extensive data collected from eutrophic fens, such as sedge communities, meadows or reed beds (MALZAhn \& Fedyk 1982; RACZYŃsKi et al. 1983 a, b; GĘBCZYŃSKA \& RACZYŃSKi 1997). In Poland, dispersed, quantitatively restricted samples of Micromammalia were taken from open peatmoss communities or pine bog forests of Roztocze (Ziomek 1998), Bieszczady Mts (BuchalczyK \& Markowski 1979), Biebrza Basin (RACZYŃSKi et al. 1983 b), Świętokrzyskie Mts (SAŁATA-PiŁACiŃSKA \& RACHOWIAK 1990; WypióRKIEWICZ 2001), Wielkopolska (RACHOWIAK 1989), and Pomerania (PiŁacińska et al. 1999; Ciechanowski 2001; Ciechanowski 2009; Ciechanowski \& ANTCZAK 2011). Although one may assume that there are no truly tyrphobiontic species of European rodents or shrews, the structure of small-mammal assemblages inhabiting this peculiar group of habitats has not been analyzed in detail. The aim of this paper is to analyse the quantitative and qualitative structure of small-mammal assemblages inhabiting various Sphagnum peat bogs of 4 distinct regions of Poland, compared to other wetland habitats. We seek also for differences between regions, internal zones of bog habitats (e.g. centre vs. margin), productivity (oligotrophic vs. mesotrophic mires), and different levels of anthropogenic degradation. Additionally, 
we review data obtained by other researchers in former studies of small mammals inhabiting peatmoss mires and the associated bog woodlands.

\section{Study area}

The studied peat bogs were located in Pomerania (Baltic Sea Coast and Pomerania Lakeland), Orawa-Nowy Targ Basin (Kotlina Orawsko-Nowotarska, in the Carpathians), Świętokrzyskie Mts, Wielkopolska, and the Lubusz Land. They varied in topology and vegetation structure, although some features were common to all of them. Treeless communities included peatmoss hummocks (Sphagnetalia magellanici), peatmoss hollows and some sedge swamps (Scheuzerietalia palustris), while woodlands consisted of pine bog forests (Vaccinio uliginosi-Pinetum). At all sites, a significant percentage of moss layer was dominated by various species of Sphagnum (e.g. S. magellanicum, S. rubellum, S. cuspidatum, S. fallax). The most frequent vascular plants included ericaceous shrubs (common cranberry Vaccinium oxycoccos, bog bilberry Vaccinium uliginosum, bog rosemary Andromeda polifolia, marsh Labrador tea Ledum palustre and heath Calluna vulgaris) as well as sedges (tussock cottongrass Eriophorum vaginatum, white beak-sedge Rhynchospora alba, and - locally - mud sedge Carex limosa). On transitional mires and on marginal slope (lagg) zones of raised bogs, several other species were frequent: slender sedge Carex lasiocarpa, bog-bean Menyanthes trifoliata, bog arum Calla palustris (almost exclusively at lowland sites) or common cottongrass Eriophorum angustifolium. The only frequent trees were Scots pine Pinus sylvestris, downy birch Betula pubescens, and (only in the Orawa-Nowy Targ Basin) rhaetic pine Pinus $\times$ rhaetica, which is a hybrid of P. mugo and P. sylvestris (Koczur 2006; PAWlaczyK et al. 2005; Herbichowa et al. 2007). Short characteristics of particular peat bogs are given below, with UTM coordinates in brackets. The numbers correspond to numbers of locations shown in Fig. 1.

Orawa-Nowy Targ Basin (names of bogs from ŁAJCZAK 2006):

1. Puścizna Mała (DV18): large raised bog (125 ha), subject to traditional hand cutting of peat and harvesting of peatmoss (ZAJĄC 2004). Two trap-lines were set in 2 habitats: a cupola overgrown with Sphagnum, rhaetic pine, heath, and other ericaceous shrubs; and very wet lagg zone with peatmoss and sedges.

2. Baligówka (DV18): large raised bog (275 ha), subject to traditional peat mining in the lagg zone. Six trap-lines were set, in 6 habitats: a well-preserved, treeless cupola with abundant peatmoss; drained cupola overgrown with heath, bog bilberry, and marsh Labrador tea; wet lagg zone with abundant peatmoss and tufts of cottongrass; pine bog forest (with Scots pines) growing on a former peat extraction area; and wet and dry meadows developed on the former peat bog.

3. Puścizna Rękowiańska (DV18): large raised bog (over 335 ha), with no cupola remaining intact (the whole was formerly a peat extraction area as a result of industrial peat mining). Two trap-lines were set, in 2 habitats: a stand of pines planted on dikes between peat extraction pits (partially filled with water and overgrown with Sphagnum); and (for comparison) on adjacent meadow, developed on minerotrophic fen peat. 


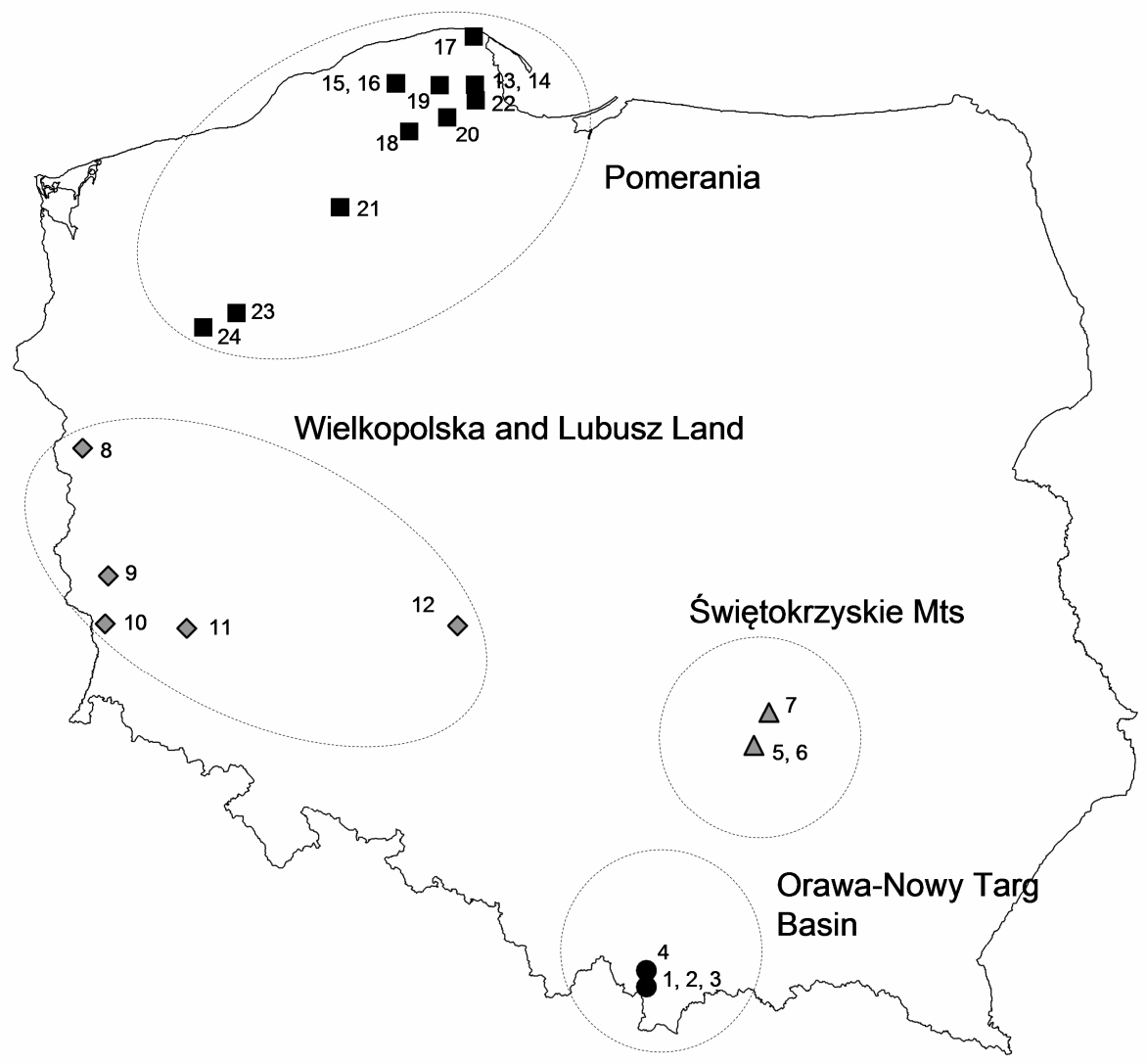

Fig. 1. Location of Polish peat bogs where small mammals were trapped, classified to particular regions

4. "Bór za Lasem Kaczmarka" (DV17): large raised bog (116 ha), in the past subject to industrial peat mining (locally down to the mineral substratum) and recently traditional hand cutting of peat (ZAJĄC 2004). Four trap-lines were set, in 4 habitats: a treeless cupola with peatmoss, ericaceous shrub and dwarf rhaetic pines; lagg zone with cottongrass and scarce peatmoss; former peat extraction area with planted birches; meadow developed on the former peat bog.

Świętokrzyskie Mountains (see also SAŁATA-PıŁACIŃSKA \& RACHOWIAK 1990):

5. Białe Ługi (DB82): large nature reserve (407 ha), protecting transitional mire, with the central part dominated by treeless peatmoss communities with abundant tussock cottongrass, surrounded by large stands of pine bog forests.

6. Słopiec (DB82): small nature reserve (8 ha), protecting a mosaic of peatmoss hummocks and hollows with small sedges (including bottle sedge Carex rostrata), dwarf pines and willows. 
7. Mokry Bór (DB94): area of strict protection (38 ha) of Świętokrzyski National Park, covered almost exclusively by forests, including extensive patches of pine bog forest.

\section{Wielkopolska and the Lubusz Land}

8. Lipiennikowe Bagno (VU80): 2 separate transitional mires or quaking bogs (8.I near lake Oczko; 8.II near lake Głębiniec), surrounded by pine and birch bog forests, forming a mosaic with several types of meso- and eutrophic wetlands (lakes, alluvial forests with black alder).

9. "Wrzosiec koło Piasecznej" (WT02): small nature reserve (40 ha), protecting sub-Atlantic Sphagnum peat bog with Erica tetralix, surrounded by mostly coniferous forests.

10. Żurawie Bagno (WS09): small nature reserve (42 ha), protecting transitional bog with Drosera rotundifolia, surrounded by mostly coniferous forests.

11. Torfowisko Borówki (WS59): small nature reserve (37 ha), protecting transitional bog and pine bog forest around shallow dystrophic lakes.

12. Small transitional bog (CCO0) near villages Dębicze and Klon. Patch of peatmoss and tufted sedges adjacent to a temporary pond; site surrounded by pine plantations.

Pomerania (Baltic Sea Coast and Pomerania Lakeland):

13. Torfowisko Borowo (CF24): small raised bog (7.5 ha), mostly covered by pine bog forest with undergrowth of birches and few patches of open peatmoss hummocks and hollows (see also CiECHANOWSKI 2001).

14. Torfowisko Zawiat (CF24): small raised and transitional bog (3.7 ha) with floating mats of Sphagnum and pine bog forest around a dystrophic lake; marginal zone with tufts of soft rush Juncus effusus (see also CIECHANOwSKI 2001).

15. Czarne Bagno (XA64): large raised bog (102 ha), protected as a nature reserve; vegetation heavily affected by anthropogenic drainage (numerous ditches), intensive industrial peat mining, and fires. Small mammals were collected from 5 trap-lines, located in reed bed with intact Sphagnum layer; on floating mat of peatmoss around a dystrophic lake; in desiccated pine and birch bog forest; wet heath with Erica tetralix; and its regeneration stages after peat fires (see also CIECHANOWSKI \& ANTCZAK 2011).

16. Łebskie Bagno (XA64): large raised bog (111 ha), protected as a nature reserve; in spite of intensive peat mining in the past, natural vegetation remarkably well preserved. Small mammals were collected from 5 trap-lines, located on treeless bog with a mosaic of Sphagnum hummocks and hollows; Erica heath with sparse pines on desiccated peat; and pine bog forests of various age and origin (see also CIECHANOWSKI \& ANTCZAK 2011).

17. Bielawa (CF27): large nature reserve (721 ha), protecting remains of a much larger sub-Atlantic raised and transitional bog, heavily affected by drainage, peat mining and long-lasting fires. Three trap-lines were set in 3 habitats: peatmoss-cottongrass association surrounding a dystrophic lake; reed bed with peatmoss adjacent to a mesotrophic pond; and association of soft rush and Sphagnum spp. 
18. Jeziorka Chośnickie (XA71): large (213 ha) nature reserve, protecting a complex of raised bog, quaking bogs, and dystrophic lakes, with peatmoss hummocks as well as pine and birch bog forest.

19. Kurze Grzędy (XA94): large raised bog (170 ha) with a well-preserved cupola, complex of transitional mires and 4 dystrophic lakes, all protected as a nature reserve; affected by artificial drainage in the past. Small mammals were collected from 4 trap-lines, located in partially treeless peatmoss hummocks, pine bog forest, and floating mat around a small lake (see also CIECHANOWSKI 2009).

20. Staniszewskie Błoto (CF02): large raised bog (130 ha) with a clearly uplifted cupola; affected by artificial drainage in the past. Small mammals were collected from 6 trap-lines, located in various developmental stages of pine bog forest (from the mature one to semi-open peatmoss hummocks overgrown with scattered young pines) and along the ditches (see also CIECHANOWSKi 2009).

21. Bocheńskie Błoto (XV36): small transitional mire (16 ha), formed by terrestrialization of a lake, protected as a nature reserve. Treeless peatmoss communities surrounded by pine bog forest.

22. Martenki (CF23): small transitional mire ( $\sim 3 \mathrm{ha})$ with extensive floating mats of Sphagnum around numerous peaty pools (pits resulting from peat extraction, filled with water); partially mesotrophic conditions resulted in frequent occurrence of bulrush Typha sp. along with several species typical for raised bogs (sundew Drosera sp., cranberry).

23. Głodne Jeziorka (WU79): complex of raised and transitional bogs, including floating mats of Sphagnum and dense communities of small sedges around 5 dystrophic lakes (0.1-0.9 ha), located in the north-eastern part of Drawa National Park.

24. Small raised bog (WU58), adjacent to postglacial Lake Rokiet, surrounded by forest of the buffer zone of Drawa National Park (see also PIŁACIŃSKA et al. 1999).

\section{MATERIALS AND METHODS}

We captured small mammals in 4 different types of traps. In most cases, we used conical pitfalls made of metal sheets (50 cm deep, Ø $15 \mathrm{~cm}$, PUCEK 1969); no bait was placed in the pitfalls. We also used live traps and snap traps baited with fried bread, or apples, oats, and sunflower seeds. In the Świętokrzyskie Mts, Wielkopolska, and the Lubusz Land, we applied Polish wooden box live traps (internal chamber: $60 \mathrm{~mm}$ in height, $70 \mathrm{~mm}$ in width, $150 \mathrm{~mm}$ in length), with vertically closing door after an animal steps on a movable floor-part. Metal live traps, used in Pomerania, (identical in design with model MŽP by ZAO 'Naučno-kommerčeskaja firma RÉT', Moscow) measured $140 \mathrm{~mm}$ in length, $70 \mathrm{~mm}$ in width and $70 \mathrm{~mm}$ in height. On 4 peat bogs we determined species identity of dead small mammals, collected by entomologists and arachnologists from Barber pitfall traps (plastic cups, $\varnothing 7 \mathrm{~cm}$, filled with propylene glycol), set up for epigeic invertebrates.

In total, we trapped small mammals on 25 peat bogs (8.I and 8.II were treated separately). At every bog, 1-6 trap-lines (in total 62) were set in various habitats. In the Orawa-Nowy Targ Basin, we conducted research on 4 peat bogs, setting up 14 trap-lines (each consisting of 20 pitfalls). Every trap line operated during 5 subse- 
quent nights and days (1400 trap-nights in total). We conducted trapping in the OrawaNowy Targ Basin in June and August 2002 and 2003. In the Świętokrzyskie Mts, we conducted trapping on 3 bogs. At every bog, 30-40 snap traps and/or 20 live traps operated 2-3 nights (420 trap-nights in total). In Wielkopolska and the Lubusz Land, we studied small mammals on 6 peat bogs. At every bog, 40 snap traps and/or 20-90 live traps operated 2-4 nights (1020 trap-nights in total). In Pomerania, we conducted study on 9 peat bogs in various periods of July-August 1998-2009. At every bog, 15-30 pitfall traps and/or 10-30 live traps operated 2-9 nights each time (1596 trapnights in total). Additionally, small mammals were collected from Barber traps on 4 peat bogs. On Czarne Bagno and Łebskie Bagno, we set up the traps from late June to late November 2006, resulting in 15100 trap-nights (both peat bogs with 5 lines, each consisting of 10 traps). On Kurze Grzędy and Staniszewskie Błoto, apart from metal pitfalls and live traps, also Barber traps for invertebrates operated for 8 days, resulting in 480 trap-nights (both peat bogs with 3 lines, each consisting of 10 traps).

\section{RESULTS}

In total, we captured 598 small mammals, representing 12 species: common shrew Sorex araneus Linnaeus, 1758; pygmy shrew Sorex minutus Linnaeus, 1766; Eurasian water shrew Neomys fodiens (Pennant, 1771); Mediterranean water shrew Neomys anomalus Cabrera, 1907; bank vole Myodes glareolus (Schreber, 1790); root vole Microtus oeconomus (Pallas, 1776); field vole Microtus agrestis (Linnaeus, 1761); common vole Microtus arvalis (Pallas, 1778); harvest mouse Micromys minutus (Pallas, 1771); yellow-necked mouse Apodemus flavicollis (Melchior, 1834); striped field mouse Apodemus agrarius (Pallas, 1771); and wood mouse Apodemus sylvaticus (Linnaeus, 1758). Mean species richness per peat bog was 4.4 ( $\mathrm{SD} \pm 1.73$, range 1-7). The most frequent species was $S$. minutus, recorded on 23 of 25 peat bogs, followed by $S$. araneus (22 bogs), M. agrestis (16 bogs), M. glareolus (14 bogs), and A. flavicollis (13 bogs) (Figure 2). Pygmy shrew was also the most numerous small mammal recorded on the studied peat bogs, making up $26.4 \%$ of all individuals captured (Appendix 1). It was the only species recorded at as many as 9 trap-lines: the cupola and former peat extraction area of "Bór za Lasem Kaczmarka" (bog no. 4), Jeziorka Chośnickie (bog no. 18), the whole Łebskie Bagno (all 5 trap-lines - bog no. 16) and floating mat of peatmoss in Kurze Grzędy (bog no. 19). At 9 of 26 trap-lines with pitfalls, only 1-2 species of the genus Sorex were trapped. In the total catch, Soricomorpha accounted for $43.1 \%$ and Rodentia for $56.9 \%$ of all individuals. Semi-aquatic or typical wetland species (N. fodiens, N. anomalus, M. oeconomus) constituted only $2.5 \%$ of captured mammals.

In the Orawa-Nowy Targ Basin, where only pitfalls were used, shrews constituted $74.7 \%$ of trapped individuals. Among them also S. minutus predominated, although the percentage of $S$. araneus was higher there than in any other region. Rodents made up the remaining $25.3 \%$ of captures, with $M$. glareolus being the most numerous, while no individuals of $A$. flavicollis were ever trapped there (Table 1).

In Pomerania, $S$. minutus strongly predominated in the sample. Shrews constituted $66.7 \%$ of mammals trapped there, and among the remaining $33.3 \%$ (rodents), the most numerous was A. flavicollis, followed by M. glareolus and M. agrestis 


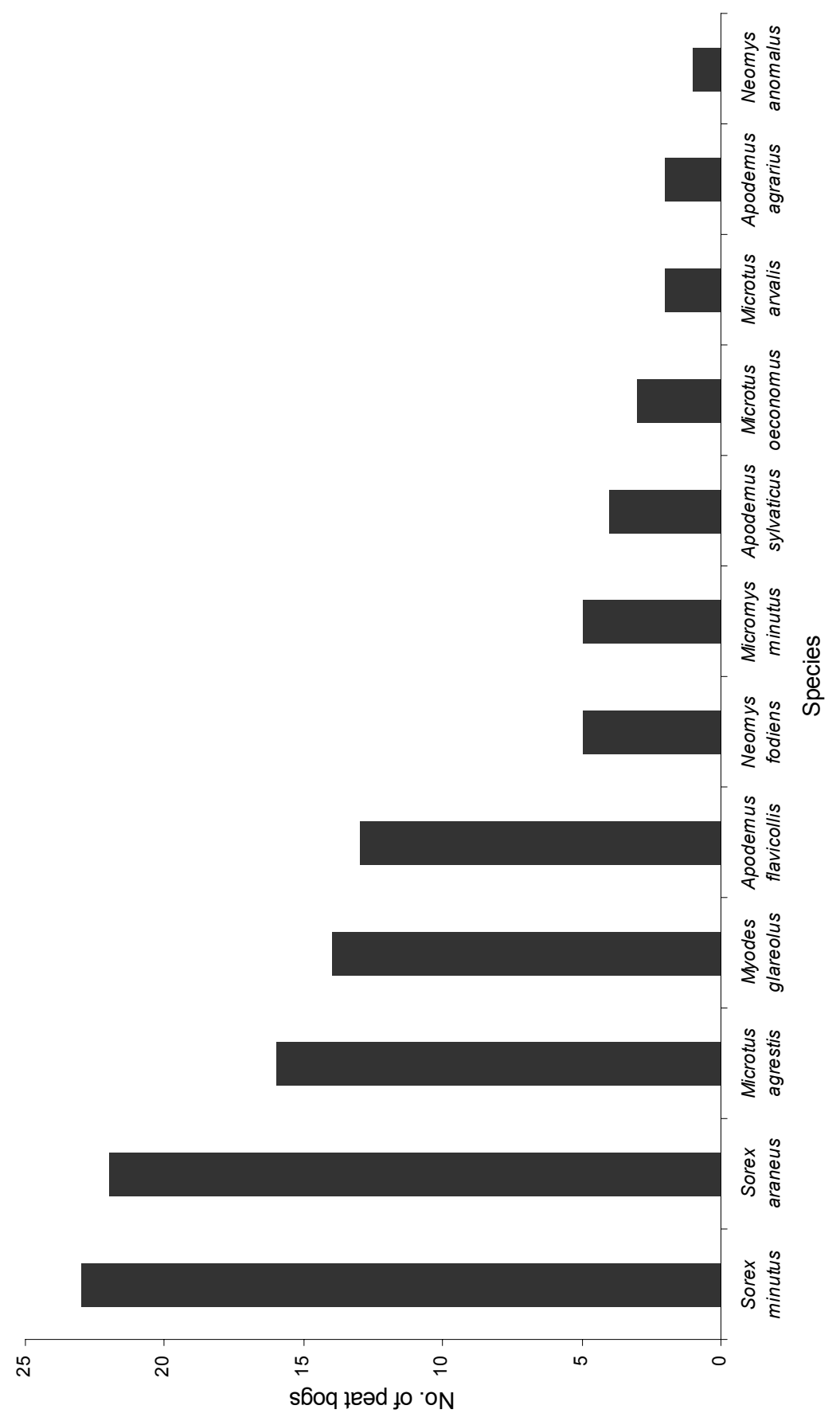


(Table 1). If only pitfall captures were taken into account, shrews in Pomerania constituted $73.2 \%$ of the sample. It was the only region where we captured a few individuals of $M$. oeconomus and $N$. anomalus on peat bogs. The latter species (2 individuals) was trapped in the marginal zone of the large sub-Atlantic mire of Bielawa, in reed bed with Sphagnum on the shore of a shallow, mesotrophic pond.

Table 1. Number of individuals and dominance index (\%) of small-mammal species on Sphagnum peat bogs in 4 studied regions of Poland

\begin{tabular}{|c|c|c|c|c|c|c|c|c|c|c|}
\hline \multirow{3}{*}{ Species } & \multirow{2}{*}{\multicolumn{2}{|c|}{$\begin{array}{c}\text { Orawa-Nowy } \\
\text { Targ Basin }\end{array}$}} & \multicolumn{4}{|c|}{ Pomerania } & \multirow{2}{*}{\multicolumn{2}{|c|}{$\begin{array}{c}\begin{array}{c}\text { Święto- } \\
\text { krzyskie Mts }\end{array} \\
\begin{array}{c}\text { snap and live } \\
\text { traps }\end{array}\end{array}$}} & \multirow{2}{*}{\multicolumn{2}{|c|}{$\begin{array}{c}\text { Wielkopolska } \\
\text { and Lubusz } \\
\text { Land } \\
\text { snap and live } \\
\text { traps }\end{array}$}} \\
\hline & & & \multicolumn{2}{|c|}{ conical pitfalls } & \multicolumn{2}{|c|}{ all traps } & & & & \\
\hline & $N$ & $\%$ & $N$ & $\%$ & $N$ & $\%$ & $N$ & $\%$ & $N$ & $\%$ \\
\hline Sorex araneus & 31 & 34.1 & 11 & 15.5 & 20 & 9.1 & 15 & 13.5 & 24 & 13.6 \\
\hline Sorex minutus & 36 & 39.6 & 33 & 46.5 & 104 & 47.3 & 1 & 0.9 & 17 & 9.7 \\
\hline Neomys fodiens & 1 & 1.1 & 6 & 8.5 & 6 & 2.7 & 0 & 0.0 & 1 & 0.6 \\
\hline Neomys anomalus & 0 & 0.0 & 2 & 2.8 & 2 & 0.9 & 0 & 0.0 & 0 & 0.0 \\
\hline Myodes glareolus & 11 & 12.1 & 0 & 0.0 & 18 & 8.2 & 34 & 30.6 & 62 & 35.2 \\
\hline Microtus oeconomus & 0 & 0.0 & 5 & 7.0 & 5 & 2.3 & 0 & 0.0 & 0 & 0.0 \\
\hline Microtus agrestis & 3 & 3.3 & 5 & 7.0 & 14 & 6.4 & 20 & 18.0 & 35 & 19.9 \\
\hline Microtus arvalis & 4 & 4.4 & 0 & 0.0 & 1 & 0.5 & 0 & 0.0 & 0 & 0.0 \\
\hline Micromys minutus & 4 & 4.4 & 2 & 2.8 & 6 & 2.7 & 0 & 0.0 & 0 & 0.0 \\
\hline Apodemus flavicollis & 0 & 0.0 & 6 & 8.5 & 38 & 17.3 & 14 & 12.6 & 34 & 19.3 \\
\hline Apodemus agrarius & 0 & 0.0 & 1 & 1.4 & 5 & 2.3 & 27 & 24.3 & 0 & 0.0 \\
\hline Apodemus sylvaticus & 1 & 1.1 & 0 & 0.0 & 1 & 0.5 & 0 & 0.0 & 3 & 1.7 \\
\hline Total & 91 & 100.0 & 71 & 100.0 & 220 & 100.0 & 111 & 100.0 & 176 & 100.0 \\
\hline No. of species & & & & & & & & & & \\
\hline
\end{tabular}

At all 3 peat bogs in the Świętokrzyskie Mts, where only snap and live traps were used, rodents constituted $85.6 \%$ of the sample, among which the most numerous were $M$. glareolus and A. agrarius. The unusually high dominance index of the latter was the result of trapping at only one peat bog, i.e. Słopiec (Appendix 1). Few shrews were captured there (14.4\%), mostly $S$. araneus.

In Wielkopolska and the Lubusz Land, where also snap and live traps (both with plant bait) were applied, $76.3 \%$ of mammals consisted of rodents, with M. glareolus being dominant, followed by $M$. agrestis and A. flavicollis. The remaining $23.7 \%$ 
(shrews) consisted mostly of $S$. araneus, but with a relatively high percentage of $S$. minutus (Table 1).

Trapping success for pitfalls amounted to 7.8 ind. per 100 trap- nights in Pomerania and 7.0 ind. per 100 trap-nights in the Orawa-Nowy Targ Basin. The corresponding value for snap and live traps in the Świętokrzyskie Mts was 26.4, while in Wielkopolska and the Lubusz Land, 14.9.

Raised bogs in the Orawa-Nowy Targ Basin revealed noticeable differences in trapping success and species richness of Micromammalia among particular habitats. The poorest assemblage was recorded on treeless cupolas, where only the 2 species of Sorex were captured regularly and 2 species of rodents appeared there accidentally. The most diverse and abundant assemblages were noted in pine bog forests, coniferous plantations in areas were peat was extracted in the past, and in wet, partially minerotrophic lagg zones of bogs, while the neighbouring meadows were the only habitats where M. agrestis was captured (Table 2).

Table 2. Trapping success (number of individuals per 100 trap-nights) and species richness of small mammals in various habitats of Sphagnum peat bogs in the Orawa-Nowy Targ Basin (combined results for bogs no. 1-4). I = treeless cupola with peatmoss hummocks; II = desiccated cupola; III = pine bog forests; IV = lagg zone; $\mathrm{V}=$ former peat extraction areas; $\mathrm{VI}=$ meadows on former peat bog or in neighbourhood

\begin{tabular}{lrrrrrr}
\hline \multirow{2}{*}{ Species } & \multicolumn{7}{c}{ Habitat type } \\
\cline { 2 - 6 } & I & II & III & IV & V & VI \\
\hline Sorex araneus & 2.7 & 2.0 & 2.5 & 3.3 & 0 & 1.5 \\
Sorex minutus & 2.3 & 4.0 & 6.0 & 2.3 & 2.0 & 1.0 \\
Neomys fodiens & 0 & 0 & 0.5 & 0 & 0 & 0 \\
Neomys anomalus & 0 & 0 & 0 & 0 & 0 & 0 \\
Myodes glareolus & 0 & 0 & 3.5 & 1.3 & 0 & 0 \\
Microtus oeconomus & 0 & 0 & 0 & 0 & 0 & 0 \\
Microtus agrestis & 0 & 0 & 0 & 0 & 0 & 0.8 \\
Microtus arvalis & 0 & 1.0 & 0 & 0.3 & 0 & 0.5 \\
Micromys minutus & 0.3 & 0 & 0 & 0.3 & 0 & 0.5 \\
Apodemus flavicollis & 0 & 0 & 0 & 0 & 0 & 0 \\
Apodemus agrarius & 0 & 0 & 0 & 0 & 0 & 0 \\
Apodemus sylvaticus & 0 & 0 & 0.5 & 0 & 0 & 0 \\
\hline Total & 5.3 & 7.0 & 13.0 & 7.7 & 2.0 & 4.3 \\
No. of individuals & 16 & 7 & 26 & 23 & 2 & 55 \\
Species richness & 3 & 3 & 5 & 5 & 1 & 5 \\
No. of trap-nights & 300 & 100 & 200 & 300 & 100 & 400 \\
\hline
\end{tabular}


Comparison of selected bogs with similar size, trapping effort, and the same type of trap reveals also differences in trapping success and species richness among sites that differ in trophic status and level of human impact. Five species of Micromammalia were collected from Barber traps on Czarne Bagno. This is a Baltic raised bog that underwent a period of large-scale habitat degradation due to industrial peat-mining and following development of secondary vegetation. Łebskie Bagno is a similar, closely located site that retained original bog communities in much better condition, but only one species (S. minutus) was collected and its abundance was about 10 times lower there (Table 3). Among 3 small Pomeranian bogs, the most diverse mammalian

Table 3. Trapping success (number of individuals per 100 trap-nights) and species richness of small mammals at 2 large Pomeranian raised bogs: with vegetation heavily affected by peat mining, drainage and fires (Czarne Bagno - bog no. 15) or with well-preserved patches of original vegetation (Łebskie Bagno - bog no. 16). All individuals were collected from Barber pitfall traps (cups) for epigeic invertebrates

\begin{tabular}{lcc}
\hline \multirow{2}{*}{ Species } & \multicolumn{2}{c}{ Peat bog } \\
\cline { 2 - 3 } & Czarne Bagno & Lebskie Bagno \\
\hline Sorex araneus & 0.03 & 0 \\
Sorex minutus & 0.44 & 0.05 \\
Microtus agrestis & 0.01 & 0 \\
Microtus arvalis & 0.01 & 0 \\
Micromys minutus & 0.05 & 0 \\
\hline Total & 0.54 & 0.05 \\
Species richness & 5 & 1 \\
No. of trap-nights & 7550 & 7550 \\
\hline
\end{tabular}

Table 4. Trapping success (number of individuals per 100 trap-nights) and species richness of small mammals at 3 small Pomeranian Sphagnum peat bogs: one mesotrophic (Martenki, no. 22) and 2 oligotrophic (Borowo, no. 13, and Zawiat, no. 14). All included individuals were captured in conical pitfalls in mid-September

\begin{tabular}{lccc}
\hline \multirow{2}{*}{ Species } & \multicolumn{3}{c}{ Peat bog } \\
\cline { 2 - 4 } & Martenki & Borowo & Zawiat \\
\hline Sorex araneus & 2.3 & 1.3 & 0 \\
Sorex minutus & 9.2 & 4.7 & 3.4 \\
Neomys fodiens & 2.3 & 0 & 0 \\
Microtus oeconomus & 2.3 & 0 & 0 \\
Microtus agrestis & 3.4 & 0 & 0 \\
Micromys minutus & 1.1 & 0 & 0.7 \\
\hline Total & 20.7 & 6.0 & 4.0 \\
Species richness & 6 & 2 & 2 \\
No. of trap-nights & 87 & 150 & 149 \\
\hline
\end{tabular}


assemblage was recorded on transitional mire with obviously mesotrophic conditions. At 2 other sites with clearly oligotrophic conditions (raised bogs), only 2 species were trapped and their relative abundance was 3-5 times lower (Table 4).

\section{DISCUSSION}

\section{Effect of trap type and evaluation of methods}

Some observed differences in the quantitative structure of small-mammal assemblages obviously result from differences in the types of traps used. In particular, this applies to the predominance of rodents in the Swiętokrzyskie Mts and southwestern Polish lowlands and the predominance of shrews in the 2 remaining regions. Some authors demonstrate that pitfall traps are more efficient in trapping shrews, while snap traps and live traps, in trapping rodents (e.g. RATHKE \& BRÖRING 2005; NiCOLAS \& COLYN 2006). However, certain studies revealed only strong underestimation of shrews by snap and live traps, while the effectiveness of all 3 types of traps (including pitfalls) for catching rodents remained similar (PUCEK 1969; O'BRIEN et al. 2006). Judging from the way how every type of trap operates, deep pitfalls $(50 \mathrm{~cm})$ may simply reflect a proportion of major taxa much closer to reality. Standard baits used in snap and live traps strongly attract only rodents, overestimating their share in the assemblage, while pitfalls catch all epigeic mammals by chance, at least if they are deep enough to prevent high-jumping animals (e.g. Apodemus species) from escape. Thus we treat results from trapping in deep, conical pitfalls in Pomerania and the Orawa-Nowy Targ Basin as a main point of reference for our discussion on specificity of small-mammal assemblages inhabiting Sphagnum peat bogs. In contrast, shallow and narrow Barber traps, although filled with the preserving solution, are supposed to strongly underestimate larger species, especially rodents. The latter hypothesis is additionally supported by results of PANKAKOSKI's (1979) study that compared the effectiveness of small cone pitfalls (depth $35 \mathrm{~cm}, \varnothing 11.5 \mathrm{~cm}$ ) and snap traps. The cited author found the catch index of A. flavicollis and M. agrestis in pitfalls 5 times lower than in snap traps.

\section{Species composition of Micromammalia on Polish bogs}

Comparison of our results with the other - though scarce - studies from Polish peat bogs can be only very restricted due to the application of partially different trapping methods. In the Roztocze region (SE Poland), 3 continental raised bogs were inhabited by the poorest assemblage of Micromammalia (4 species) among all 15 studied habitats. Being dominated by $M$. glareolus and devoid of typical wetland species, like $N$. fodiens or M. oeconomus (Table 5), that animal community appeared to be extremely impoverished assemblage of small forest mammals, located at the opposite end of the scale than eutrophic fens, covered by reed and sedge beds (15 species). Mature pine bog forests ( 7 localities) hosted a more diverse small-mammal fauna ( 7 species), although with the same dominant species. Their fauna lacked semiaquatic taxa and was still much poorer than the fauna of alder fen woods, developed in minerotrophic conditions on fens (12 species). However, trapping success of small mammals in open raised bog and pine bog forests was not so low in Roztocze, as it 
reached up to 20.9 and 16.1 individuals per 100 trap-nights, respectively (ZIOMEK 1998). Also in the Bieszczady Mts, the assemblage of Micromammalia inhabiting raised bog was the poorest among 8 studied habitats and consisted of only 5 species. However, it included northern birch mouse Sicista betulina Pallas, 1779, i.e. the species captured in no other Polish raised bog (BuchalczyK \& MARKowski 1979).

In the middle part of the Biebrza Valley, 2 patches of pine bog forest appeared to be the second poorest habitat in terms of both species richness ( 5 species) and trapping success (4.0 ind. per 100 trap-nights), strongly contrasting with alder fen woods (13 species and 29.0 ind. per 100 trap-nights). In that study, pitfalls were regularly applied, along with snap and live traps. The results were the most similar to ours from Pomerania and the Orawa-Nowy Targ Basin, with noticeable predomination of $S$. minutus (RACZYŃSKI et al. 1983 b) (Table 5).

Table 5. Species composition and trapping success of small mammals on some Polish Sphagnum peat bogs in earlier literature: Bieszczady (BuchalczYK \& MARKowsKi 1979), Roztocze (ZiomeK 1998), Białe Ługi (WYPIÓRKIEWICZ 2001, the same bog as in our study), Biebrza Valley (RACZYŃSKI et al. 1983 b), Chlebowo (RACHOWIAK 1989). Explanations: * raised bog; ${ }^{a}$ pine bog forest; ${ }^{1}$ live traps; ${ }^{2}$ snap traps; ${ }^{3}$ pitfall traps; ,,?" lack of data

\begin{tabular}{|c|c|c|c|c|c|c|c|c|c|c|}
\hline \multirow{2}{*}{ Species } & \multirow{2}{*}{$\begin{array}{c}\text { Bieszczady } \\
\text { Mts*123 } \\
\\
N \\
\end{array}$} & \multicolumn{2}{|c|}{ Roztocze*2 } & \multicolumn{2}{|c|}{ Roztocze $^{a_{23}}$} & \multicolumn{2}{|c|}{ Białe Lugia1 } & \multirow{2}{*}{$\begin{array}{c}\text { Biebrza } \\
\text { Valley }^{\text {a123 }} \\
\\
\%\end{array}$} & \multicolumn{2}{|c|}{ Chlebowo* } \\
\hline & & $N$ & $\%$ & $N$ & $\%$ & $N$ & $\%$ & & $N$ & $\%$ \\
\hline Sorex araneus & 4 & 10 & 21 & 25 & 17 & 21 & 34 & 25 & 127 & 31 \\
\hline Sorex minutus & 2 & 3 & 6 & 6 & 4 & 3 & 5 & 32 & 27 & 7 \\
\hline Neomys fodiens & 0 & 0 & 0 & 0 & 0 & 0 & 0 & 0 & 20 & 5 \\
\hline Myodes glareolus & 13 & 32 & 68 & 99 & 69 & 10 & 16 & 27 & 29 & 7 \\
\hline Microtus oeconomus & 0 & 0 & 0 & 0 & 0 & 0 & 0 & 12 & 151 & 37 \\
\hline Microtus agrestis & 0 & 2 & 4 & 6 & 4 & 4 & 7 & 0 & 21 & 5 \\
\hline Apodemus flavicollis & 6 & 0 & 0 & 2 & 1 & 9 & 15 & 0 & 8 & 2 \\
\hline Apodemus agrarius & 0 & 0 & 0 & 3 & 2 & 10 & 16 & 4 & 25 & 6 \\
\hline Apodemus sylvaticus & 0 & 0 & 0 & 3 & 2 & 4 & 7 & 0 & 0 & 0 \\
\hline Sicista betulina & 1 & 0 & 0 & 0 & 0 & 0 & 0 & 0 & 0 & 0 \\
\hline Total catch & 26 & 47 & 100 & 144 & 100 & 61 & 100 & 100 & 408 & 100 \\
\hline No. of trap-nights & 420 & \multicolumn{2}{|c|}{225} & \multicolumn{2}{|c|}{930} & \multicolumn{2}{|c|}{$?$} & $?$ & \multicolumn{2}{|c|}{1808} \\
\hline Trapping success & 6.2 & \multicolumn{2}{|c|}{20.9} & \multicolumn{2}{|c|}{16.1} & \multicolumn{2}{|c|}{$?$} & 4.0 & \multicolumn{2}{|c|}{22.6} \\
\hline Species richness & 5 & \multicolumn{2}{|c|}{4} & \multicolumn{2}{|c|}{7} & \multicolumn{2}{|c|}{7} & 5 & \multicolumn{2}{|c|}{8} \\
\hline No. of peat bogs & 1 & \multicolumn{2}{|c|}{3} & \multicolumn{2}{|c|}{7} & \multicolumn{2}{|c|}{1} & 2 & \multicolumn{2}{|c|}{1} \\
\hline
\end{tabular}


Unexpected results were obtained by Rachowiak (1989) from the large ( 300 ha) raised bog in Chlebowo near Ryczywół (Wielkopolska). Among small mammals trapped there, the most numerous was $M$. oeconomus, a species considered as typical of eutrophic fens, overgrown by large, tufted sedges (RACZYŃsKI et al. $1983 \mathrm{a}, \mathrm{b}$, GĘBCZYŃSKA \& RACZYŃSKI 1997). Also the frequent occurrence of $N$. fodiens is worth noticing in this peculiar site (Table 5). However, vegetation of the peat bog in Chlebowo was heavily affected by peat mining and numerous drainage ditches, probably diverging from typical ombrotrophic mires. Although Sphagnum dominated in the moss layer of some fragments, communities of tufted sedges (Carex canescens, $C$. stellulata, C. rostrata) formed most of the herb layer (RACHOWIAK 1989), structurally resembling sedge fens and, consequently, resulting in a high abundance of root voles.

\section{Occurrence of rodents}

Except for Chlebowo, treeless ombrotrophic mires appeared to be quite poor in rodents near the southern range of distribution of this habitat. Even in southern Sweden, as well as in coastal parts of Norway almost no microtine rodents have ever been captured in peatlands. By contrast, in northern Sweden, M. agrestis is as common on mires as in secondary habitats (abandoned fields and reforested areas), while M. oeconomus is still abundant only on fertile alkaline fens on calcareous bedrock and occasionally inhabits transitional bogs. Further north, in the Norwegian province of Finnmark, poor Sphagnum peat bogs are inhabited by numerous M. oeconomus and M. agrestis, accompanied by some northern red-backed voles Myodes rutilus (Pallas, 1779 ) and grey-sided voles Myodes rufocanus (Sundevall, 1846) (Boström \& Hansson 1981). In Siberian taiga, both M. oeconomus and M. agrestis are the only rodents captured in the peripheral parts of large, treeless peatmoss bogs, sometimes accompanied by wood lemming Myopus schisticolor (Liljeborg, 1844) (Koneva 1983).

The scarcity of rodents on ombrotrophic mires of western and southern Europe requires a more detailed explanation. The high water level may often exclude digging of dens, so on eutrophic fens, tufts of large sedges and dense reed provide suitable microhabitats for building of nests. However, these are hardly available on Sphagnum peat bogs, where vegetation is dominated by bryophytes, sparse, short sedges, and ericaceous shrubs, while peatmoss hummocks might not be an optimal substitute. Also trophic constraints may further restrict small herbivorous mammals there. Green leaves of forbs, sedges and grasses predominate in the diet of M. oeconomus (BostRÖM \& HANSSON 1981), while many ericaceous shrubs typical for bogs are rich in toxic phenolics, terpenoids and tannins, making them much less palatable for folivores (JENSEN \& DONCASTER 1999). On the other hand, digestibility of mosses seems to be very poor for most animals, because of the high content of some phenolic secondary compounds. Sphagnum itself contains much less phosphorus, calcium and magnesium than other mosses. Moreover, acidity may further reduce its usability as food, thus it is avoided even by specialised bryophages, like wood lemmings (EsKELINEN 2002). M. agrestis on Swedish fens consumes large quantities of green mosses, but on Sphagnum bogs it switches to sedges and vegetative parts of either bog rosemary or cranberries (BOSTRÖM \& HANSSON 1981). However, those findings show also 
quite high adaptive possibilities of microtine rodents, making hard any explanation why open raised bogs are avoided by them in the south but not in Arctic and boreal zones.

Apodemus flavicollis and M. glareolus on ombrotrophic mires are subject to other trophic constraints. As partially granivorous, these forest rodents rely strongly on the crop of heavy seeds (AULAK 1970), which are almost unavailable in unproductive habitats, such as raised bogs, where the only tree species are pines and birches. On the other hand, fruiting of cranberries may attract these rodents to visit even open bogs, as they are known for a high plasticity in diet, supplemented by berries, mushrooms and invertebrates (BOSTRÖM \& HANSSON 1981). In mature pine bog forest, the degree of cover in the dwarf-shrub layer is much higher, creating shelter against predators, thus it may promote the regular use of this habitat by some generalist forest rodents, even if their abundance is still lower than in almost any other type of woodland (e.g. PuCEK 1983). This might be also the case of hygrophilous M. agrestis, which is not so restricted to the open habitats as $M$. oeconomus and may be a constant element of forest fauna (AULAK 1970). In Canadian ombrotrophic peatlands, the abundance of small mammals was higher near forest edges than at bog centres and some species positively responded to vegetation cover (MAZEROLle et al. 2001).

The presence of several small rodent species on Sphagnum peat bogs might be just accidental, related to immigration from surrounding agricultural lands, clearings and glades, e.g. during population outbreaks. Such immigration explains the high abundance of $A$. agrarius on the peat bog in Słopiec. This small mire is adjacent to farmland and it is already known that $A$. agrarius migrates to patches of undisturbed vegetation after tillage on fields in autumn (PIŁACIŃSKA 2005).

\section{Occurrence of shrews}

Low species richness, low population densities (deduced from low trapping success), and low percentage of rodents might be treated as typical features of smallmammal assemblages inhabiting at least open peatmoss communities of raised bogs in Poland. The high dominance of shrews is associated with their invertebrate-based diet, unaffected directly by unfavourable physicochemical properties of bog plants. All studies based on pitfalls reveal that pygmy shrew $S$. minutus is the most numerous insectivore species in Polish bogs, and probably the most frequent small mammal there. In well-preserved, treeless parts of oligotrophic Sphagnum peat bogs with high water level, it might be the only regularly occurring species. Also in Britain, $S$. minutus greatly outnumbered $S$. araneus on blanket bogs (BUTTERFIELD et al. 1981) and acid-peat moorland, but it was outnumbered by the latter in lowland forests and grasslands (YALDEN 1981). In western Norway, pygmy shrew was the only soricid occurring on bogs, although it inhabited a variety of neighbouring forest habitats, often in much higher numbers (SKARTVEIT et al. 2005)

Few factors may cause the dominance of $S$. minutus in these harsh conditions. Compared to common shrew, pygmy shrew is more hygrophilous and recorded more frequently in closer distance to water (RYCHLIK 2000), although its preferred habitats are eutrophic wetlands, more precisely alder fen woods (RACZYŃSKI et al. 1983b; GĘBCZYŃSKA \& RACZYŃSKi 1997; ZıOMEK 1998). Moreover, it is an epigeal forager, 
so surface-dwelling spiders and harvestmen are its most frequent prey. Thus the species may be unaffected by high water table. In contrast, $S$. araneus is mostly a hypogeal forager, feeding extensively on soil-dwelling earthworms (CHURCHFIELD \& RYCHLIK 2006). Meanwhile, soils on raised bogs are almost devoid of earthworms because of low pH values, contrary to eutrophic fens (SPEIGHT \& Blackith 1983; ELLENBERG \& STRUTT 1988). On the other hand, S. araneus is considered behaviourally dominant over $S$. minutus in cases of interspecific aggression (RYCHLIK \& ZWOLAK 2006). The smaller and less competitive shrew species may be thus forced out of most productive habitats and find refuge in suboptimal patches, where they are able to survive because of their low per capita food requirements (HANSKI \& KAIKUSALO 1989). Pygmy shrew may utilize quite unexpected prey in such conditions. In June 1982, one of us (B. Piłacińska) observed S. minutus eating a fly stuck to a leaf-trap of a sundew on the shore of oligotrophic lake Duże Gacno in the Tuchola Forest (Bory Tucholskie, Pomeranian Lakeland). Among 16 habitats of the boreal zone of Russia, bogs host the fourth poorest assemblage of Sorex shrews (mean 3.1 species) and are the third poorest habitat in terms of relative shrew abundance there. However, the smallest species were more abundant in wetter habitats and more frequent in the least productive habitats (SCHEFTEL \& HANSKi 2002).

Interestingly, semi-aquatic Neomys species were rarely encountered on ombrotrophic mires. Several factors might be responsible for that situation. Permanent bodies of open water are available only at some of the studied bogs, even if water level in the peat deposit is high (cf. PAWLACZYK et al. 2005; LAJCZAK 2006; HerBichowa et al. 2007). Moreover, even if a peat bog is developed around a lake or contains flooded peat extraction pits, dystrophic waters are characterized by a very low productivity and abundance of zoobenthos in the littoral zone, as compared to eutrophic waters (RADWAN et al. 2003). Thus these waters may not be able to sustain significant populations of water shrews, as they are relatively large soricids with higher per capita energy requirements and may avoid less productive habitats (cf. HANSKI \& KAIKUSALO 1989).

\section{Effect of productivity and habitat degradation}

Higher abundance and species richness of Micromammalia is an indicator of improved trophic conditions of a bog, e.g. caused by contact with nutrient-rich ground water and reflected in vegetation typical for transitional bog. This was the case of small bogs in Pomerania and lagg zones of large bogs in the Orawa-Nowy Targ Basin. It may also be an indicator of anthropogenic habitat degradation, mostly associated with drainage for forestry purposes, as well as peat mining, especially on an industrial scale. This was also the case of Canadian bogs, where both species richness and abundance of small mammals increased significantly with percentage of area mined (MAZERolle et al. 2001). The mechanism linking human-induced degradation and increase in mammalian abundance is associated with lowering water table, following drainage. This makes digging of dens by mammals possible, but also accelerates peat decomposition and release of nutrients. The latter increases ecosystem productivity and opens a succession of secondary vegetation. Shrubs and trees overgrow Sphagnum hummocks, increasing the spatial complexity of habitats. Moreover, 
hardly palatable, stenotopic bog plants are replaced in this process by e.g. grasses, like purple moor grass Molinia caerulea (Ellenberg \& Strutt 1988; Herbichowa et al. 2007), readily eaten by herbivorous microtines (BostrÖM \& HANSSON 1981). Such processes, although beneficial for the commonest, ubiquitous species of Micromammalia, must be considered disadvantageous from the conservationists' point of view, as they lead to destruction of exclusive refuges for specialized and often threatened, tyrphobiontic invertebrates and plants.

Acnowledgements: We would like to thank W. Cichocki (the Tatra Museum in Zakopane), A. Biała, U. Anikowska, A. Nalewaja, E. Ratajczak and A. Przesmycka for their help with field work, as well as R. Zwolak for extensive language correction. We are also grateful to R. Jaskuła and M. Jankowska for collection of small mammals from their Barber traps on Czarne and Łebskie Bagno, and to J. Błażuk for data about small mammals captured by him on Jeziorka Chośnickie.

\section{REFERENCES}

AulaK W. 1970. Small mammal communities of the Białowieża National Park. Acta Theriol. 15: 465-515.

Boström U., Hansson L. 1981. Small rodent communities on mires: implications for population performance in other habitats. Oikos 37: 216-224.

Buchalczyk T., Markowski J. 1979. Ssaki Bieszczadów Zachodnich [Mammals of the Western Bieszczady Mts]. Ochrona Przyrody 42: 119-150 (in Polish).

Butterfield J., Coulson J. C., Wanless S. 1981. Studies on the distribution, food, breeding biology and relative abundance of the Pygmy and Common shrews (Sorex minutus and S. araneus) in upland areas of northern England. J. Zool. 195: 169-180.

Churchfield S., Rychlik L. 2006. Diets and coexistence in Neomys and Sorex shrews in Białowieża forest, eastern Poland. J. Zool. 269: 381-390.

Ciechanowski M. 2001. Drobne ssaki (Micromammalia) wybranych siedlisk Trójmiejskiego Parku Krajobrazowego [Small mammals (Micromammalia) of the selected habitats of Trójmiejski Landscape Park]. Bad. Fizjogr. Pol. Zach., ser. C 48: 65-76 (in Polish).

Ciechanowski M. 2009. Ssaki [Mammals]. In: Przyroda rezerwatów Kurze Grzędy i Staniszewskie Błoto na Pojezierzu Kaszubskim [The nature of Kurze Grzędy and Staniszewskie Błoto reserves in the Kashubian Lakeland] (Herbich J., Ciechanowski M., Eds), pp. 256-264, Fundacja Rozwoju Uniwersytetu Gdańskiego, Gdańsk (in Polish).

Ciechanowski M., Antczak J. 2011. Ssaki [Mammals]. In: Przyroda rezerwatów Łebskie Bagno i Czarne Bagno [The nature of Łebskie Bagno and Czarne Bagno reserves] (HerBichowa M., Herbich J., Eds), pp. 170-179, Fundacja Rozwoju Uniwersytetu Gdańskiego, Gdańsk (in Polish).

Ellenberg H., Strutt G. K. 1988. Vegetation Ecology of Central Europe. Edition 4. Cambridge University Press.

ESKELINEN O. 2002. Diet of the wood lemming Myopus schisticolor. Ann. Zool. Fenn. 39: 49-57.

GĘBCZYŃSKA E., RACZYŃSKI J. 1997. Fauna i ekologia drobnych ssaków Narwiańskiego Parku Narodowego [Fauna and ecology of small mammals of the Narwiański National Park]. Parki Nar. Rez. Przyr. 16: 37-61 (in Polish).

Hanski I., KaikUSalo A. 1989. Distribution and habitat selection of shrews in Finland. Ann. Zool. Fenn. 26: 339-348.

Herbichowa M., Pawlaczyk P., Stańko R. 2007. Conservation of Baltic raised bogs in Pomerania, Poland. Experience and Results of the LIFE04NAT/PL/000208 PLBATBOGS Project. Naturalists Club (Klub Przyrodników), Świebodzin. 
Jensen S., Doncaster C. P. 1999. Lethal toxins in non-preferred foods: how plant chemical defences can drive microtine cycles. J. Theor. Biol. 199: 63-85.

Koczur A. 2006. Importance of vegetation in the Orawsko-Nowotarskie peat bogs to biological diversity in the Polish Carpathians. Acta Agroph. 7: 383-393.

KonEvA I. V. 1983. Gryzuny i zajceobraznye Sibiri i Dal'nego Vostoka [Rodents and lagomorphs of Siberia and Far East]. Akademiya Nauk SSSR, Sibirskoe Otdelenie, Institut Geografii Sibiri i Dal'nego Vostoka. Izdatel'stvo "Nauka", Sibirskoe Otdelenie, Novosibirsk (in Russian).

ŁAJCZAK A. 2006. Peatbogs of Orawsko-Nowotarska Basin. Development, human impact, renaturalisation and selected problems of protection. Instytut Botaniki im. W. Szafera, Polska Akademia Nauk. Kraków.

Malzahn E., FedyK S. 1982. Micromammalia of the cultivated Wizna fen. Acta Theriol. 27: 25-43.

Mazerolle M. J., Drolet B., Desrochers A. 2001. Small-mammal responses to peat mining of south-eastern Canadian bogs. Can. J. Zool. 79: 296-302.

Nicolas V., Colyn M. 2006. Relative efficiency of three types of small mammal traps in an African rainforest. Belg. J. Zool. 136: 107-111.

NordQuist G. E. 1992. Small mammals. In: The patterned peatlands of Minnesota (Wright H. E., Coffin B., Aaseng N., Eds), pp. 85-110, University of Minnesota Press, Minneapolis.

O’Brien C., McShea W. J., Guimondou S., Barriere P., Carleton M. D. 2006. Terrestrial small mammals (Soricidae and Muridae) from the Gamba Complex in Gabon: species composition and comparison of sampling techniques. Bull. Biol. Soc. Washington 12: 353-363.

PANKAKOSKI E. 1979. The cone trap - a useful tool for index trapping of small mammals. Ann. Zool. Fennici 16: 144-150.

Pawlaczyk P., Herbichowa M., Stańko R. 2005. Ochrona torfowisk bałtyckich. Przewodnik dla praktyków, teoretyków i urzędników [Protection of Baltic peat bogs. Guidline for practicioners, theoreticians and public officials]. Wydawnictwo Klubu Przyrodników, Świebodzin (in Polish).

PIŁACIŃSKA B. 2005. Wybrane aspekty ekologii gryzoni z wysp leśnych w krajobrazie rolniczym [Selected aspects of rodent ecology from forest islands in agricultural landscape]. Wydawnictwo Naukowe UAM, Poznań (in Polish).

PiŁacińska B., Zıomek J., Bajaczyk R. 1999. Drobne ssaki Drawieńskiego Parku Narodowego [Small mammals of the Drawieński National Park]. Bad. Fizjogr. Pol. Zach., ser. C 46: 95106 (in Polish).

PuCEK Z. 1969. Trap response and estimation of number of shrews in removal catches. Acta Theriol. 28: 403-426.

PuceK M. 1983. Habitat preference. In: Ecology of the Bank Vole (Petrusewicz K., Ed.), pp. 31-40, Acta Theriol. 28 Suppl 1.

Raczyński J., Fedyk S., GęBczyŃska Z., Pucek M. 1983a. Distribution of Micromammalia against natural differentiation of the Biebrza Valley habitats. Pol. Ecol. Stud. 10: 425-445.

Raczyński J., Fedyk S., Gębczyńska Z., Pucek M. 1983b. Drobne ssaki środkowego i dolnego basenu Biebrzy [Small mammals of the Middle and Lower Biebrza Basins]. Zesz. Probl. Postęp. Nauk Rol. 255: 297-328 (in Polish).

RACHOWIAK P. 1989. Drobne ssaki wybranych biotopów torfowiska „Bagno” w Chlebowie [Small mammals in selected biotopes of peatbog 'Bagno' in Chlebowo]. Bad. Fizjogr. Pol. Zach., ser. C 38: 86-98 (in Polish).

Radwan S., PŁaska W., Sender J., Zwolski W., Wojciechowska W. 2003. Structure of the biocenosis in three Polesie Lubelskie region (eastern Poland) shallow lakes of different trophy. Acta Agroph. 1: 501-512.

RATHKE D., BRÖRING U. 2005. Colonization of post-mining landscapes by shrews and rodents (Mammalia: Rodentia, Soricomorpha). Ecol. Engin. 24: 149-156. 
RYchLIK L. 2000. Habitat preferences of four sympatric species of shrews. Acta Theriol. 45, Suppl. 1: $173-190$.

RYchLIK L., ZwOLAK R. 2006. Interspecific aggression and behavioural dominance among four sympatric species of shrews. Can. J. Zool. 84: 434-448.

Salata-Pilacińska B., Rachowiak P. 1990. Badania nad drobnymi ssakami (Micromammalia) Krainy Świętokrzyskiej [Studies of small mammals (Micromammalia) of the Świętokrzyskie Mts Region]. Fragm. Faun. 33: 307-334 (in Polish).

Scheftel B. I., HANSKi I. 2002. Species richness, relative abundance and habitat use in local assemblages of Sorex shrews in Eurasian boreal forests. Acta Theriol. 47: 69-79.

Skartveit J., Pommeresche R., Langhelle G., Byrkjedal I., Solhøy T. 2005. Distribution of Sorex minutus and Sorex araneus (Mammalia: Insectivora) within a forest area in Western Norway. Fauna Norv. 25: 55-62.

Speight M. C. D., Blackith R. E. 1983. The animals. In: Ecosystems of the world 4A. Mires: swamp, bog, fen and moor. General studies (Gore A. J. P., Ed.), pp. 349-365. Elsevier, Amsterdam-Oxford-New York.

WyPIÓRKIEWICZ J. 2001. Ssaki rezerwatu Białe Ługi [Mammals of the Białe Ługi reserve]. In: Rezerwat torfowiskowy „Białe Ługi” [Peatbog reserve „Białe Ługi”] (ŻureK S., Ed.), pp. 249-257. Wydawnictwo Homini, Bydgoszcz (in Polish).

YALDEN D. W. 1981. The occurrence of the Pigmy shrew Sorex minutus on moorland, and the implications for its presence in Ireland. J. Zool. 195: 147-156.

ZıомеK J. 1998. Drobne ssaki (Micromammalia) Roztocza. Część I. Micromammalia wybranych biotopów Roztocza Środkowego [Small mammals (Micromammalia) of the Roztocze. Part II. Micromammalia of the selected biotopes in Central Roztocze Upland]. Fragm. Faun. 41: 93-123 (in Polish).

ZAJAC E. 2004. Process of self-regeneration of the post-harvested areas of peatbogs in the OrawaNowy Targ Basin. Electr. J. Pol. Agr. Univ. Environ. Devel. 7, 1. Available Online http://www. ejpau.media.pl. 